\title{
Editorial
}

\section{The Play's the Thing Wherein We'll Catch the Conscience of the Times}

\author{
by Kevin A. Quarmby. Published in 2018 Issue 1.
}

TWENTY-FIRST-CENTURY REVIEWERS OF EARLY MODERN DRAMATIC PERFORMANCES, WHO APPRECIATE the vagaries of professional theatrical production, might feel justified in expressing delighted surprise at the topical politicized resonances they encounter on their nations' stages. Surprise because, as anyone involved in the creative industries knows, the "opening night" of any performance is the culmination of months and months, in some cases years, of planning. Theatrical reviewing thus becomes an exercise in criticizing or praising an end product, not an entire process. A performance is both a birth and, inevitably, a slow though glorious death. We are invited to attend the culmination of this creative process. For political and social issues to dominate theatrical practice, creatives must be prescient in their undertakings, must tap into a collective zeitgeist without appearing too heavily to moralize or polemicize. With national division and polarization continuing to threaten our security and that of future generations, such politicization is inevitable, if not always completely successful.

Often, however, we seem ignorant of the seer-like quality demanded by so many production houses. Why? Because theatres present us with fully-formed dramatic entities that allow us to ignore a play's original amorphous literary state, its development in the minds of a creative few (producers, directors, designers), and its eventual realization by a group of actors. "The play's the thing," as Hamlet advises us, though a thing mature, vibrant, alive, and, most strange of all, tantalizingly ephemeral. Where better to analogize our own sense of mortality than the staged theatrical product? No sooner is a production realized than its death is announced in the obituary columns of the theatrical review.

Freed from considering the extended and extensive creative process, our end-result opinions about an array of theatrical events - that bear certain generic or historicized characteristics in common-might be skewed in favour of seeing them only as individuated and isolated cultural expressions. We collectively can experience or ignore their topical messages without guilt or concern. This 2018 edition of Scene offers an insight into the disparate immediacy of early modern dramatic production on twenty-first-century stages in the US, Canada, and the UK, in a year when politics and social upheaval seem like inescapable aspects of our lives. Whatever our colour 
on the political spectrum, we cannot escape the onslaught of news media that dictates for good or ill our sense of outrage, fear, or shame. The review essays that make up this edition highlight this politicization of today's early modern play performances in sometimes contentious, though always impassioned ways. That they do so offers proof that those entrusted with staging these productions should be celebrated not only for their creativity, but also for their oracular zeitgeisting skills.

The first to discuss the imagistic potential of early modern drama in 2018 is Gretchen E. Minton, whose analysis of Henry $V$ at the Oregon Shakespeare Festival paints a fascinating picture of an oft-performed but politically ambiguous Shakespeare play. As Minton's incisive observations confirm, the OSF chose both stylization and visual imagery to promote its anti-jingoistic stance. Minton's descriptive analysis confirms the anti-war rhetoric of the OSF production at a time when militarism and nationalistic pride has returned as a potent force on national and international stages. The theatre of war literally and metaphorically manifested in Ashland's festival atmosphere, its actors engaging in social commentary both laudable and, as the strewn bodies Minton describes silently confirm, ultimately ineffectual when faced with lebensraum expansionism, separatist jingoism, and intense religious fervour associated with this Henry V's torturous conflict.

If the universal politics of war dominated Oregon Shakespeare's venture into embattled France then the universality of political nuance shrouded London's Bridge Theatre production of Julius Caesar, described in meticulous detail by Erin E. Kelly. Of course, by 2018, conflicting discourse seemed symptomatic of national polarization on a global scale. Media outlets from the left and right of the political spectrum-though rarely, it seemed, from in between-beat their steady drums of dissent or support for any incumbent governing regime. As news gatherers around the world looked on, nations seemed wracked with apoplexy-easy targets, one suspects, for theatre companies eager to invest topicality in their early modern offerings. In the UK, the Bridge Theatre's Julius Caesar was not immune to such readily available analogizing. As Kelly describes, the production pointedly evoked the adrenaline-punched political rally, with blaring rock music and ubiquitous red MAGA-like caps emblazoned not with their Trumpian "Make America Great Again" slogan but the predictable "CAESAR" motif. Even the production's design colour palette barely masked the anti-Fascistic, anti-Nuremburg Rally polemic at its core.

Despite the overt political associations that Kelly notes in her review, the design conceit of the Bridge production negatively impacted its audience, many of whom were standing and inevitably herded like rally attendees. With this Julius Caesar proving a physically and emotionally challenging construct, Kelly's concern for the potential psychological damage inflicted on the incidental crowd participants highlights her questioning of the extent that our theatre companies 
should explore and explain their overt analogous messages by enlivening the experience of civil conflict and mass herd-mentality manipulation. As Kelly notes, such choices should at least be questioned. It is one thing intellectually to make these production decisions in the selfcongratulatory confines of an aesthetically-cosseted pre-production meeting room. It is another to impose these choices on a public without consideration of the needs of the multiple constituencies we should strive to attract to the theatre-needs far more urgent than our artistic onanism might dictate.

A missed opportunity for considering multiple constituencies was likewise evident in the BMO Theatre Centre's collaborative semi-staged reading of John Lyly's Galatea by The University of British Columbia (UBC), Vancouver's Bard on the Beach company, and Oecologies. Jamie Paris describes how the nine-person cast rehearsed for five days and performed their swiftlyconstructed version on the sixth, scripts in hand. This speedy creative process added to the perception of Galatea as a play for our times, with its complex consideration of gender, class, and the environment offering an open invitation to explore issues of twenty-first century importance. Paris discusses, however, the problem of the production's promotional focus, which too closely associated Lyly's complex drama with the notion of "Shakespeare." Galatea's latent potential as an antidote to the heteronormative wedding-day lovers of Shakespearean comedy, with which the pre-production publicity machine most desired to associate the play, negatively impacted Galatea's queer potential. Because it was held up against the Shakespearean touchstone of creative merit (undoubtedly not by this production's academic advisers, though most likely by the producing venue and associated companies), Lyly's powerful engagement with gender and the environment became inevitably lost in bardolatrous translation.

Gender also ruled in an alternative Elsinore evoked in East Tennessee State University Department of Theatre \& Dance's self-proclaimed All-Female Hamlet, a production that, as Brooke Johnson describes, sought to emasculate this quintessentially male play. Performed on a university campus that fulfilled its dutiful respect for equity, diversity, and inclusion, this sixtyminute seven-actor All-Female Hamlet attempted to escape Hamlet's binary gender narrative. In her analysis of this de-gendering experiment, Johnson observes, however, an unexpectedly nuanced humanization among certain stereotypical characters in Hamlet that seemingly highlighted gender's all-pervasive presence in the play.

With the humanizing effect of non-gendering so popular a play as Hamlet in mind, Erin E. Kelly's second UK review, of the Royal Shakespeare Company's The Duchess of Malfi, explored a production that seemed characterized not by the human, but by a rubberized stage-property animal carcass that dominated the acting space. Interrogating the RSC's concept-driven production, Kelly takes issue with the play's narrowly-focused topicality, its \#MeToo era message 
drowned in fake blood and gratuitous sexual violence. Obviously the consequence of preproduction decision-making, the forced-topicality of this RSC venture imposed an aesthetic moral compass on its audience. By unconsciously colluding with the voyeuristic portrayal of aggressive male sexual display, the company elevated that aggressive behaviour to the same fantasy-shock genre blamed for nurturing violence among contemporary youth. Sex and shock and blood are, unfortunately, commercial. The fetishization of The Duchess of Malfi that Kelly describes seemed uncomfortably counter to the effect the RSC so obviously desired.

While the RSC both commented on and commoditized the sexual power discrepancies in Webster's drama and in contemporary society by paring down the play's narrative to some phallocentric angle measure of the entire plot's arc, an entirely different exploration of relationship commodification was evident in the Seattle Shakespeare Company's Timon ofAthens, reviewed by Sean Henry. Commenting on the completist rarity value of this play, Henry highlights the localized relevance of a production that successfully re-gendered the Timon role, while also offering its barely masked commentary on local Seattle-based issues linked to corporate business, healthcare, and workers' rights.

From the rarely played and unlovely to the sublimely loveable, the Vancouver-based Bard on the Beach's production of As You Like It, liberally peppered with Beatles songbook musicality and Forest of Arden frolics (localized to British Columbia's Okanagan region), is celebrated in Melissa Walter and Emily Warwick's review. Commenting on this production's temporal shift between the 1960s and 1970s via its knockabout wrestling humour and Beatlemania, Walter and Warwick note how ubiquitous hippie-style As You Like It productions have become.

While this Canadian version was proof positive of the irrepressible suitability of As You Like It for any localized venue and age-in this instance, a stylized vision of twentieth-century Vancouverits design-concept universality relied entirely on evoking the superficiality of hippie-inspired cultural innocence. Not by any means a bad choice, though nonetheless a noticeable one, the production's avowed intent seemed to recreate an innocent world. By escaping the politicized tub-thumping of many other early modern concept-driven theatrical ventures, as Walter and Warwick demonstrate, the societal divisiveness of 2018 could be countered by a production that united its audience in a community of singalong Beatles nostalgia.

Scene's "Production Notices" section includes two short descriptions of the 2018 Utah Shakespeare Festival by Jim Volz. USF's casting in The Merchant of Venice of the astonishing Lisa Wolpe as Shylock confirmed her status as the foremost Shakespearean male impersonator of the twenty-first century. With Wolpe setting the textually coherent tone of the play, Volz notes how this straightforward telling of the story avoided any force-feeding of its political message. 
Rather, the USF empowered its audiences to make its own connections to the nation's polarization because of race and/or creed.

In contrast, and not dissimilar to the Vancouver production of As You Like It, USF's The Merry Wives of Windsor relied heavily on the musical celebration of its comic creation, despite the \#MeToo recriminatory potential of the bawdy rogue, Falstaff. Because the company's vision was squarely focused on entertainment, one could be excused for questioning whether Falstaff's inevitable mocked cuckold comeuppance could be considered sufficient, or whether, as this introduction to our 2018 Scene reviews suggests, creative and stylistic decisions made months, sometimes more than a year, in advance of eventual performance cannot possibly reflect social issues with true zeitgeist immediacy. Perhaps the USF recognized that a polarized nation in times of heightened anger, fear, and stress, needed its sense of "community celebration," if only for the few short hours of a theatrical performance. Perhaps also those productions most guilty of polemicizing early modern drama should consider the effectiveness rather than the moral imperative of their creative decisions, which might advertise a production house's commendable (or otherwise) political leanings, while at the same time cementing division among those consumers of early modern theatre that should be the true reason why such performances are staged.

Whatever the answer to this perennial problem, it behooves us to remember that when, in the final artistic flowering of the theatrical product, we recognize the topicality of our age enacted on our nations' stages, instead of praising the political discourse with which our creatives engage, we should question why the social problems and concerns these productions address seem never to be resolved. If we really are "reflecting" the age in these early modern revivals, then perhaps the image that we see in our collective mirrors offers little more than proof that lessons rarely, if ever, get learned, and theatrical moralizers rarely, if ever, change entrenched attitudes no matter how worthy the messages they preach. Scene 2018 offers its snapshot of theatrical endeavour, a grainy daguerreotype of a societal battlefield in which directors and designers, and only occasionally actors, determine the course of their respective wars, which sometimes manifest as momentary lulls in the fighting as audiences join in a no-man's-land community where fun for fun's sake at last, and for a moment, disarms us. 